\section{Penegakan Hukum \\ Abstract Terhadap Pelaku Tindak Pidana Kekerasan Dalam Rumah Tangga (Studi Penelitian Pada Polrestabes Medan)}

\author{
Oleh \\ Syarifuddin ${ }^{1}$ \\ syarifali1983@gmail.com
}

The purpose of law enforcement is to harmonize the relationship of the values that are outlined in the rules, and to create, maintain and preserve peace in social life. Women and children are very vulnerable to becoming victims in all forms of violence or criminal acts, including violence in the domestic sphere. This research is descriptive analysis because it only explains about legal arrangements, law enforcement, as well as barriers and efforts to enforce the law by Medan Police against perpetrators of criminal acts of domestic violence (Research Study at Medan Police).

The regulation of domestic violence law is contained in the Article 4 of Law of the Republic of Indonesia Number 23 of 2004 concerning Domestic Violence which states that the purpose of domestic violence is to prevent all forms of domestic violence, protect victims, take action against perpetrators, and maintain the integrity of the household. The application of the law by the police against the perpetrators of criminal acts of domestic violence prioritizes prevention, protection of victims, and maintaining household integrity. Barriers and efforts in law enforcement are that the regulations contained in PKDRT Law have not been integrated with other statutory regulations for law enforcement against criminal acts of domestic violence, so that the police strive to deal with restorative justice in order to improve and maintain the integrity of the households of the people dealing with the law.

Keywords: Law Enforcement, Perpetrator, Criminal Acts, Domestic Violence.

\begin{abstract}
Abstrak
Tujuan penegakan hukum untuk menyerasikan hubungan nilai-nilai yang terjabarkan dalam kaidah-kaidah, serta menciptakan, memelihara dan mempertahankan kedamaian pergaulan hidup. Perempuan dan anak sangat rentan menjadi korban dalam segala bentuk kekerasan atau tindak pidana, tidak terkecuali juga kekerasan dalam lingkup rumah tangga. Penelitian bersifat deskriptif analisis karena hanya menjelaskan tentang pengaturan hukum, penegakan hukum, serta hambatan dan upaya penegakan hukum oleh Kepolisian Polrestabes Medan terhadap pelaku tindak pidana kekerasan dalam rumah tangga (Studi Penelitian Pada Polrestabes Medan).
\end{abstract}

Pengaturan hukum kekerasan dalam rumah tangga terdapat pada Pasal 4 UndangUndang Republik Indonesia Nomor 23 Tahun 2004 Tentang Kekerasan Dalam Rumah Tangga menyebutkan tujuan KDRT adalah untuk mencegah semua bentuk KDRT, melindungi korban, menindak pelaku, serta memelihara keutuhan rumah tangga. Penerapan hukum oleh kepolisian terhadap pelaku tindak pidana kekerasan dalam rumah tangga lebih mengutamakan pencegahan, perlindungan korban, serta mempertahankan keutuhan rumah tangga.

Hambatan dan upaya penegakan hukum adalah belum terintegrasi peraturan yang terdapat dalam UU PKDRT dengan peraturan perundang-undangan lainnya untuk penegakan hukum terhadap tindak pidana kekerasan dalam rumah tangga, sehingga kepolisian mengupayakan penanganan dengan keadilan restorative justice demi memperbaiki serta mempertahankan keutuhan rumah tangga masyarakat yang berhadapan dengan hukum.

Kata Kunci: Penegakan hukum, Pelaku, Tindak Pidana, Kekerasan dalam Rumah Tangga.

${ }^{1}$ Dosen Tetap Fakultas Hukum UISU 
Media Komunikasi dan Informasi Hukum dan Masyarakat

\section{Pendahuluan}

\section{A. Latar Belakang}

Tujuan dari suatu perkawinan adalah membentuk keluarga (rumah tangga) yang bahagia dan kekal berdasarkan Ketuhanan Yang Maha Esa sebagaimana Amanah Pasal 1 Undang-Undang Republik Indonesia Nomor 1 Tahun 1974 Tentang Perkawinan. Kekerasaan Dalam Rumah Tangga atau KDRT bukanlah sesuatu yang asing untuk didengar akhir-akhir ini. Pemberitaan mengenai KDRT hampir setiap hari selalu menjadi bahasan berita yang menarik di tanah air. Menurut Pasal 1 Undang-Undang Republik Indonesia Nomor 23 Tahun 2004 Tentang Penghapusan Kekerasan Dalam Rumah Tangga (selanjutnya disebut UU PKDRT), menyebutkan kekerasan dalam rumah tangga adalah setiap perbuatan terhadap seseorang terutama perempuan, yang berakibat timbulnya kesengsaraan atau penderitaan secara fisik, seksual, psikologis, dan/atau penelantaran rumah tangga termasuk ancaman untuk melakukan perbuatan, pemaksaan, atau perampasan kemerdekaan secara melawan hukum dalam lingkup rumah tangga.

Penyebab utama terjadinya KDRT bertitik tolak pada kurangnya kesadaran dan pemahaman tentang hak dan kewajiban antara suami dan isteri, sehingga menimbulkan ketidak-setaraan dalam keluarga yang berakibat munculnya keegoisan Pelaku KDRT. Meskipun penyebabnya tidak dapat digeneralisir karena jenjang pendidikan yang tinggi maupun rendah. Usia dini laki-laki dan perempuan yang menikah juga dapat menjadi penyebab atau seringnya kekerasan dalam rumah tangga, selanjutnya status ekonomi maupun sosial juga dapat berpengaruh untuk memicu KDRT. Dari pejabat sampai rakyat semua berpotensi untuk dapat melakukan KDRT, kemudian agama, suku dan ras juga dapat dijadikan sebagai pemicu $\mathrm{KDRT}^{2}$.

Akibat dari KDRT yang pada umumnya dilakukan oleh laki-laki terhadap perempuan, sering sekali memaksa perempuan yang menjadi korban KDRT untuk berdiam diri/menerima keadaan, konsekuensi ini dipilih oleh perempuan sebagai korban KDRT adalah untuk melindungi nama baik keluarga. Berbagai sebab perempuan terpaksa mendiamkan perbuatan tersebut karena adanya budaya yang sudah berlaku berabad- abad bahwa istri harus patuh, taat dan mengabdi, serta tunduk pada suami. Pengorbanan seperti itu seringkali tidak mendapat imbalan berupa penghargaan yang setimpal. Memang ironis bahwa dalam rumah tangga, dimana perempuan memberikan tenaga, pikiran, cinta dan kasih sayang untuk mengurus dan merawat semua anggota yang terdapat dalam rumah tangga, justru mendapatkan kekerasan yang dilakukan oleh orang terdekat bahkan dari orang yang dicintai dan disayangi mereka. Tindak kekerasaan dominan yang dialami oleh perempuan adalah penganiayaan, perkosaan, pelecehan, atau perselingkuhan yang dilakukan oleh suami.

$$
\text { Mengatasi berbagai persoalan }
$$

kekerasan dalam keluarga atau rumah tangga itu sendiri, negara telah berupaya memberikan perlindungan dan keadilan dari berbagai bentuk kekerasan yang khususnya dilakukan suami dalam lingkup rumah tangga melalui UU PKDRT. Lahirnya UU PKDRT ini, merupakan reaksi dari gejala sosial yang tidak wajar dan terus menerus berulang. Undang-undang ini diharapkan mampu menimbulkan pencegahan dan penindakan kepada mereka yang selalu melakukan tindakan kekerasan dalam lingkup

${ }^{2}$ Badriyah Khaleed, Penyelesaian Hukum KDRT, Pustaka Yustisia, Jakarta, Cet ,I, 2015, hal. 1. 
Media Komunikasi dan Informasi Hukum dan Masyarakat

rumah tangga atau dengan kata lain bahwa undang-undang ini diharapkan dapat menjadi perlindungan serta payung hukum bagi seluruh anggota keluarga dalam rumah tangga itu sendiri.

Uraian diatas menegaskan bahwa semua pihak yang ada dalam lingkup rumah tangga tersebut dapat berpotensi menjadi pelaku tindak kekerasan dalam rumah tangga, sebaliknya juga dapat berpotensi menjadi korban. Saat ini dimasyarakat sudah terbangun suatu pandangan bahwa ketika mendengar kekerasan dalam rumah tangga maka yang menjadi sorotan yaitu kekerasan suami kepada isteri atau suami istri kepada anak. Pandangan ini didasarkan pada asumsi bahwa suami itu secara fisik lebih kuat dari pada isteri atau suami isteri lebih kuat dari anak, selain itu dilihat dari persentasenya maka sebagian besar korban kekerasan dalam rumah tangga yang terjadi di Medan adalah kaum perempuan (isteri) dan pelakunya adalah suami, walaupun ada juga suami yang menjadi korban, sesuai data yang diperoleh dari pra penelitian di Kepolisian Resort Kota Besar Medan, bahwa pada Tahun 2018 terdapat sebanyak 91 kasus KDRT, Tahun 2019 terdapat sebanyak 107 kasus KDRT, dan Tahun 2020 sampai dengan bulan Juli terdapat 44 kasus KDRT. Terkait penegakan hukum terhadap kasus KDRT, ada beberapa pelaku tindak pidana KDRT yang tidak bisa dilanjutkan dari proses penyelidikan ke proses penyidikan karena terkendala dengan bukti yang autentik (masalah alat bukti memang menjadi kendala dalam penanganan kasus KDRT). Misalnya untuk membuktikan kekerasan fisik harus ada visum padahal, seringkali terjadi hasil visum hanya menunjukkan kekerasan yang terakhir dilakukan, dimana yang kelihatan hanyalah lecet, padahal kenyataannya korban telah dipukuli tiga bulan berturut-turut, sebagian besar kekerasan yang terjadi pada korban kekerasan dalam rumah tangga adalah kekerasan psikis. Persoalannya adalah pembuktian kekerasan psikis itu tidak mudah, satu-satunya cara untuk membuktikannya adalah dengan surat keterangan dari psikolog. Selain hal tersebut diatas, aparat penegak hukum sangat hati-hati untuk memproses kasus KDRT disebabkan hubungan anatar pelaku dengan korban, yang pada umumnya adalah suami isteri.

Penegakan hukum merupakan suatu upaya negara untuk dapat memberikan keadilan terhadap setiap orang yang diduga melakukan atau terlibat dalam tindak pidana, serta memberikan perlindungan dan keadilan bagi korban tindak pidana, khususnya perempuan dan anak.

Data diatas memberikan gambaran bahwa kekerasan yang terjadi dalam rumah tangga, sebahagian besar berujung pada penganiayaan terhadap isteri (domestic violence), meskipun pasal yang terdapat dalam Kitab Undang-Undang Hukum Pidana memberikan pemberatan hukuman bagi pelaku penganiayaan yaitu pada Pasal 351, 352, 353, 354, 355 KUHP, namun Kitab Undang- Undang Hukum Pidana tidak mengaturnya dalam bab atau pasal yang tersendiri atau spesifik. Selain itu, Kitab Undang-Undang Hukum Pidana hanya mengakui kekerasan fisik sebagai bentuk kejahatan, tidak mempertimbangkan kekerasaan psikis ataupun seksual ${ }^{3}$.

Terdapat beberapa teori-teori dalam kriminologi yang relevan dengan kekerasan dalam rumah tangga, menurut teori Richard L.Davis:

${ }^{3}$ Moerdati Hadiati Soeroso, Kekerasan dalam Rumah Tangga dalam Persfektif Yuridis Viktimologi, Sinar Grafika, Cet II, Jakarta, 2011, hal. 6. 
Media Komunikasi dan Informasi Hukum dan Masyarakat

a. Biological Positivism, kejahatan atau penyimpangan perilaku dipengaruhi oleh faktor biologis. Agresivitas adalah sifat yang dibawah individu sejak lahir (faktor internal). Kekerasan yang terjadi sebagai akibat dari sifat agresif tersebut, dipandang sebagai bentuk individual pathology. Namun, dengan pendekatan bio-social pandangan tersebut dikoreksi, kemudian dikemukakan sifat agresif saja tidak akan melahirkan kekerasan/kejahatan tanpa adanya tekanan dari luar diri pelaku. Sehingga dengan kata lain individu yang memiliki agresif atau pembawa gen agresif, tidak akan melakukan kekerasan tanpa adanya tekanan dari lingkungan, seperti konflik, tekanan sosial, tekanan ekonomi, provokasi korban, dan lainnya.

b. Perspektif Teori Control

Kekerasan dalam rumah tangga dapat sebagai bentuk penyimpangan perilaku yang terjadi terutama akibat lemanya kontrol individu (pelaku) serta ketiadaan kontrol eksternal (masyarakat). Tetapi, lemahnya kontrol individu saja tidak akan menghasilkan kejahatan apabila tidak ada kesempatan atau peluang untuk itu.

c. Learning Theory

Kejahatan atau ketimpangan perilaku sebagai hasil proses belajar dalam relasi yang intim.

Berdasarkan pemikiran diatas, penulis menganggap perlu melakukan penelitian yang berjudul "Penegakan Hukum Terhadap Pelaku Tindak Pidana Kekerasan Dalam Rumah Tangga (Studi Penelitian Pada Polrestabes Medan)".

\section{B. Rumusan Masalah}

Berdasarkan latar belakang yang telah diuraikan diatas, maka rumusan masalah yang dapat dikaji dalam penelitian ini adalah sebagai berikut:

1. Bagaimana pengaturan hukum kepolisian polrestabes medan terhadap pelaku tindak pidana kekerasan dalam rumah tangga ?

2. Bagaimana penegakan hukum terhadap pelaku tindak pidana kekerasan dalam rumah tangga?

3. Bagaimana hambatan dan upaya kepolisian dalam penegakan hukum terhadap pelaku tindak pidana kekerasan dalam rumah tangga ?

\section{Metode Penelitian}

Penelitian ini bersifat deskriptif analitis, yaitu suatu metode yang digunakan untuk menggambarkan dan menganalisis mengenai situasi atau kejadian dan menerangkan hubungan antara kejadian tersebut dengan masalah yang akan diteliti.

Jenis penelitian ini adalah adalah penelitian yuridis empiris. Penelitian yuridis empiris adalah pendekatan permasalahan mengenai hal-hal yang bersifat yuridis dan kenyataan yang ada mengenai hal-hal yang bersifat yuridis. Penelitian hukum empiris atau penelitian sosiologis yaitu penelitian hukum yang menggunakan data primer. Menurut pendekatan empiris pengetahuan didasarkan atas fakta-fakta yang diperoleh dari hasil penelitian dan observasi ${ }^{4}$.

II. Hasil dan Penelitian

A. Pengaturan Hukum Kepolisian Polrestabes Medan Terhadap Pelaku Tindak Pidana Kekerasan Dalam rumah Tangga

Pembagian tugas dan kewenangan aparat penegak hukum bertujuan agar pelaksanaan tugas penegakan hukum dapat

${ }^{4}$ Ronny Hanitijo Soemitro, Metodologi Penelitian Hukum dan Jurimetri, Ghalia Indonesia, Jakarta, 2009, hal. 10 
Media Komunikasi dan Informasi Hukum dan Masyarakat

menjadi fokus, sehingga tidak terjadi duplikasi kewenangan, namun tetap terintegrasi karena antara institusi penegak hukum yang satu dengan lainnya secara fungsional ada hubungan sedemikian rupa didalam proses penyelesaian perkara pidana, dikenal juga dengan integrated criminal justice system (sistem peradilan pidana terpadu). Sistem peradilan pidana terpadu dalam KUHAP merupakan dasar bagi terselenggaranya proses peradilan pidana yang benar-benar bekerja dengan baik serta memberikan perlindungan hukum terhadap harkat dan martabat tersangka, terdakwa, atau terpidana sebagai manusia. Oleh sebab itu, setiap negara di dunia ini mempunyai sistem peradilan pidana yang meskipun secara garis besar hampir sama, namun memiliki karakter tersendiri yang disesuaikan dengan kondisi sosial masyarakat, budaya, dan politik yang dianut ${ }^{5}$. Secara sederhana sistem peradilan pidana adalah proses yang dilakukan oleh negara terhadap orang-orang yang melanggar hukum pidana. Sebagaimana yang diungkapkan Cavadino dan Dignan bahwa sistem peradilan pidana adalah " $A$ term covering all those institution which respond officially to the commission of offences, notably the police, prosecution authorities and the court'.6.

Sistem peradilan pidana yang dianut oleh KUHAP terdiri dari sub sistem yang merupakan tahapan proses jalannya penyelesaian perkara, sub sistem penyidikan dilaksanakan oleh kepolisian, sub sistem penuntutan dilaksanakan oleh kejaksaan, sub sistem pemeriksaan di sidang pengadilan dilaksanakan oleh pengadilan, dan sub sistem

${ }^{5}$ Eddy, O.S Hiariej, Criminal Justice System in Indonesia, Between Theory and Reality, Asia Law Review Vol. 2, No. 2 December 2005, Korean Legislation Research Institute, 2005, hal. 25.

${ }^{6}$ Michael Cavadino dan James Dignan, The Penal Sistem An Introduction, SAGE Publication Ltd, 1997, hal. 1. pelaksanaan putusan pengadilan dilaksanakan oleh kejaksaan dan lembaga pemasyarakatan. Untuk pelaksanaan penegakan hukum dalam bingkai sistem peradilan pidana terpadu (integrated criminal justice system), keempat institusi pelaksana dalam sistem peradilan pidana tersebut lazimnya lebih mengutamakan kebersamaan serta semangat kerja yang tulus dan ikhlas serta positif antara aparatur penegak hukum ${ }^{7}$.

Proses dalam Hukum Acara Pidana secara garis besar dapat dibagi menjadi tindakan yang mendahului pemeriksaan di muka pengadilan yang terdiri atas tingkat penyelidik/penyidik (kepolisian) dan pada tingkat penuntut umum. Ketika dalam proses penyidikan sudah terkumpul bukti-bukti yang menguatkan maka penyidik akan mengirim BAP (berkas acara pemeriksaan) kepada kejaksaan untuk kemudian kejaksaan menunjuk penuntut umum yang kemudian membuat surat dakwaan dan selanjutnya melimpahkan ke pengadilan negeri. Ketua pengadilan membentuk majelis hakim yang bertugas memanggil terdakwa, kemudian dilanjutkan dengan pemeriksaan dalam sidang pengadilan hingga akhirnya menghasilkan putusan pengadilan ${ }^{8}$.

Tahap yang mengawali proses Hukum Acara Pidana adalah diketahui terjadinya tindak pidana (delik). Perkara pidana disebut ada jika diketahui adanya tindak pidana atau peristiwa pidana atau kejahatan yang dilakukan oleh seseorang atau beberapa orang. Berbeda dengan perkara perdata, ketika inisiatif untuk mengajukan perkara diambil oleh orang-orang

\footnotetext{
${ }^{7}$ Mardjono Reksodipoetro, Sistem Peradilan Pidana Indonesia (Peran Penegak Hukum Melawan Kejahatan), Pusat Pelayanan Keadilan dan Pengabdian Hukum Universitas Indonesia, 1994, hal. 84.

${ }^{8}$ M. Taufik Makarao dan Suhasril, Hukum Acara Pidana Dalam Teori Dan Praktek, Ghalia Indonesia, Jakarta, 2004, hal. 24
} 
Media Komunikasi dan Informasi Hukum dan Masyarakat

yang merasa dirugikan maka dalam perkara pidana, inisiatif untuk mengajukan perkara pidana diambil oleh negara. Mengajukan perkara pidana di pengadilan karena adanya tindak pidana atau kejahatan. Diketahui terjadinya tindak pidana dari empat kemungkinan yaitu:

a. Tertangkap tangan (Pasal 1 Angka 19 KUHAP);

b. Laporan (Pasal 1 Angka 24 KUHAP);

c. Pengaduan (Pasal 1 Angka 25 KUHAP);

d. Diketahui sendiri atau pemberitahuan atau cara lain sehingga penyidik mengetahui terjadinya delik seperti baca di surat kabar, dengar di radio, dengar orang bercerita, dan lain-lain ${ }^{9}$.

Kitab Undang-Undang Hukum Acara Pidana sebagai hukum formiil, memiliki sepuluh asas, yaitu:

a. Perlakuan yang sama di muka hukum;

b. Praduga tidak bersalah;

c. Hak untuk memperoleh kompensasi (ganti rugi) dan rehabilitasi;

d. Hak untuk memperoleh bantuan hukum;

e. Hak kehadiran terdakwa di muka pengadilan;

f. Peradilan yang bebas, dan dilakukan dengan cepat dan sederhana;

g. Peradilan yang terbuka untuk umum;

h. Pelanggaran atas hak-hak warganegara (penangkapan, penahanan, penggeledahan dan penyitaan) harus dilakukan berdasarkan undang-undang dan dilakukan dengan surat perintah (tertulis);

i. Hak tersangka untuk diberitahu tentang persangkaan dan pendakwaan terhadapnya; j. Kewajiban pengadilan untuk mengendalikan pelaksanaan putusannya.

Berdasarkan sepuluh asas tersebut, maka dapat dikatakan bahwa KUHAP menganut due process of law (proses hukum yang adil atau layak). Suatu proses hukum yang adil pada intinya adalah hak seorang tersangka dan terdakwa untuk didengar pandangannya tentang bagaimana peristiwa kejahatan itu terjadi, dalam pemeriksaan tersangka/terdakwa berhak didampingi oleh penasihat hukum, mengajukan pembelaan, dan penuntut umum harus membuktikan kesalahannya di muka suatu pengadilan yang bebas dan dengan hakim yang tidak berpihak. Jika dilihat dari sudut kriminologi dan viktimologi sejak penangkapan tersangka, proses stigmatisasi dan viktimisasi struktural sudah berjalan. Sistem peradilan pidana terpadu adalah sistem yang mampu menjaga keseimbangan perlindungan kepentingan, baik kepentingan negara, kepentingan masyarakat, maupun kepentingan individu termasuk kepentingan pelaku tindak pidana dan korban kejahatan. Menurut Muladi, makna integrated criminal justice system ini adalah sinkronisasi dan keselarasan yang dapat dibedakan dalam:

a. Sinkronisasi struktural (structural syncronization), yaitu keserampakan dan keselarasan dalam kerangka hubungan antara lembaga penegak hukum.

b. Sinkronisasi substansial (substantial syncronization), yaitu keserampakan dan keselarasan yang bersifat vertikal dan horisontal dalam kaitannya dengan hukum positif.

Sinkronisasi kultural (cultural syncronization), yaitu keserampakan dan keselarasan dalam menghayati pandanganpandangan, sikap-sikap dan falsafah yang 
Media Komunikasi dan Informasi Hukum dan Masyarakat

secara menyeluruh mendasari jalannya sistem peradilan pidana ${ }^{10}$.

Mengamati tugas yuridis kepolisian yang sangat luas, jelas merupakan beban yang sangat berat, terlebih ditegaskan bahwa didalam menjalankan tugasnya, kepolisian harus selalu menjunjung tinggi hak-hak asasi rakyat dan hukum Negara, khususnya dalam melaksanakan kewenangannya di bidang penyidikan, ditegaskan pula agar senantiasa mengindahkan norma-norma keagamaan, perikemanusiaan, kesopanan dan kesusilaan. Beban tugas yang demikian berat dan ideal itu tentunya harus didukung pula oleh aparat penegak hukum yang berkualitas, profesional dan berdedikasi tinggi ${ }^{11}$.

Berdasarkan tugas dan wewenang kepolisian yang telah ditegaskan dalam UU Kepolisian serta diuraikan diatas, terlihat bahwa pada intinya ada dua tugas Kepolisian di bidang penegakan hukum, yaitu penegakan hukum di bidang peradilan pidana (dengan sarana penal), dan penegakan hukum dengan sarana non penal. Tugas penegakan hukum di bidang peradilan (dengan sarana penal) sebenarnya hanya merupakan salah satu atau bagian kecil saja dari tugas Kepolisian. Sebagian besar tugas Kepolisian justru terletak diluar penegakan hukum pidana (non penal). Tugas Kepolisian di bidang peradilan pidana hanya terbatas di bidang penyelidikan dan penyidikan. Tugas lainnya tidak secara langsung berkaitan dengan penegakan hukum pidana, walaupun memang ada beberapa aspek hukum pidananya. Misalnya tugas memelihara

${ }^{10}$ Romli Atmasasmita, Sistem Peradilan pidana (Perspektif Eksistensialisme dan Abolisionisme), Mandar Maju, Bandung, 1996, hal. 44.

${ }^{11}$ Barda Nawawi Arief, Beberapa Aspek Kebijaksanaan Penegakan dan Pengembangan Hukum Pidana, Citra Aditya Bakti, Bandung, 1998, hal. 4. ketertiban dan keamanan umum, mencegah penyakit-penyakit masyarakat, memelihara keselamatan, perlindungan dan pertolongan kepada masyarakat, mengusahakan ketaatan hukum warga masyarakat tentunya merupakan tugas yang lebih luas dari yang sekadar dinyatakan sebagai tindak pidana (kejahatan/pelanggaran) menurut ketentuan hukum pidana positif yang berlaku. Dari uraian diatas diungkapkan bahwa tugas dan wewenang kepolisian yang lebih berorientasi pada aspek sosial atau aspek kemasyarakatan (yang bersifat pelayanan dan pengabdian) sebenarnya lebih banyak dari pada tugas yuridisnya sebagai penegak hukum di bidang peradilan pidana. Dengan demikian dalam menjalankan tugas dan wewenangnya kepolisian sebenarnya berperan ganda baik sebagai penegak hukum maupun sebagai pelindung masyarakat untuk menggambarkan kedua tugas / peran ganda ini, Kongres PBB ke5 (Prevention of Crime and The Treatment of Offenders) pernah menggunakan istilah "Service oriented task" dan "Law enforcement duties". Perihal Kepolisian dengan tugas dan wewenangnya jelas diatur dalam UU Kepolisian. Dalam undang-undang tersebut dikatakan bahwa kepolisian adalah segala hal-ikhwal yang berkaitan dengan fungsi dan lembaga polisi sesuai dengan perundang-undangan. Dari keterangan pasal tersebut maka dapat dipahami suatu kenyataan bahwa tugas-tugas yang diemban oleh polisi sangat komplek dan rumit sekali terutama dalam bertindak sebagai penyidik suatu bentuk kejahatan.

Berdasarkan uraian diatas, tugas kepolisian yang dinilai paling efektif untuk menanggulangi terjadinya kejahatan dalam penanggulangan dan pengungkapan suatu tindak pidana adalah tugas preventif karena 
Media Komunikasi dan Informasi Hukum dan Masyarakat

tugas yang luas hampir tanpa batas, dengan begitu tugas yang digunakan adalah dengan mengedepankan asas oportunitas, utilitas dan asas kewajiban. Preventif itu dilakukan dengan 4 kegiatan pokok; mengatur, menjaga, mengawal dan patroli (disebut juga TURJAWALI). Patroli merupakan kegiatan yang dominan dilakukan, karena berfungsi untuk mencegah bertemunya faktor niat dan kesempatan agar tidak terjadi gangguan Kamtibmas/pelanggaran hukum dalam rangka upaya memelihara/meningkatkan tertib hukum serta upaya membina ketentraman masyarakat guna mewujudkan/menjamin Kamtibmas, hal ini diperlukan pengetahuan tentang bagaimana kejahatan tersebut terjadi, bagaimana keadaan lingkungan yang dipengaruhi oleh keadaan sosial, budaya dan kultur sehingga dalam penanggulangan dan pengungkapan suatu tindak kejahatan diperlukan personel yang mempelajari hal itu dan selanjutnya mendapatkan cara yang tepat dalam penanggulangannya. Fungsi patroli polisi sangat diharapkan sebagai salah satu ujung tombak dari POLRI yang bergerak dibidang refresif yustisiil yakni penyidikan yang diharapkan dapat meningkatkan kemampuan profesionalnya untuk mengantisipasi segala tipu daya dan kemampuan penjahat yang semakin hari juga semakin meningkat.

Tugas pokok polisi dalam peraturan perundang-undangan, diantaranya memberikan kewenangan kepada polisi sebagaimana diatur dalam Pasal 16 UU Kepolisian, yaitu melakukan penyelidikan dan penyidikan terhadap semua tindak pidana sesuai dengan hukum acara pidana dan peraturan perundang-undangan lainnya. Penyelidikan dan penyidikan dalam Kitab Undang-Undang Hukum Acara Pidana (KUHAP) diatur pada Pasal 4 sampai dengan
Pasal 11. Proses penyelidikan dan penyidikan tindak pidana oleh Polri melibatkan beberapa elemen utama di Polri dan unsur utama di Polri adalah Satuan Reserse Kriminal Polri (Reskrim). Peraturan Kepolisian Republik Indonesia Nomor 6 tahun 2019 Tentang Penyidikan Tindak Pidana (PERKAP Penyidikan Tindak Pidana), sebagai pedoman dalam penyelenggaraan manajemen penyidikan tindak pidana di lingkungan Polri. Apabila para Penyidik/Penyidik Pembantu dalam melaksanakan proses penyidikan tidak mengacu kepada PERKAP Penyidikan Tindak Pidana yang dijelaskan pada Pasal 42, atau para Penyidik melakukan pelanggaran, maka akan dilakukan pemeriksaan pendahuluan oleh atasan penyidik, pengawas penyidikan atau pejabat atasan pengawas penyidikan dan apabila hasil pemeriksaan pendahuluan telah ditemukan petunjuk diduga telah terjadi pelanggaran disiplin atau pelanggaran kode etik profesi Polri pemeriksaan selanjutnya diserahkan kepada fungsi Propam dan apabila terjadi tindak pidana yang dilakukan oleh Penyidik/Penyidik Pembantu dalam proses penyidikan maka proses penyidikannya diserahan kepada fungsi Reskrim. Oleh karena itu Kaur Bin Ops (KBO) Satreskrim mempunyai tugas pengawasan untuk menciptakan proses penyidikan secara transparan dan akuntabel. Pada kenyataannnya banyak proses penyidikan yang tidak dilakukan dengan transparan dan akuntabel yang ditunjukkan dengan banyak pelanggaran terhadap aturan penyidikan dan juga banyaknya penyiksaan dan tindakan tidak manusiawi selama proses penyidikan.

Uraian Pasal 3 Ayat (5) PERKAP Penyidikan Tindak Pidana menegaskan bahwa polisi sebagai aparat penegak hukum dalam melaksanakan tugasnya, tidak menjadi penghalang untuk melakukan proses 
Media Komunikasi dan Informasi Hukum dan Masyarakat

penegakan hukum yang merupakan delik biasa, apabila warga masyarakat tidak berkenan untuk membuat laporan atau pengaduan, karena ketentuan diatas memberikan amanah kepada polisi untuk dapat mengambil alih peran masyarakat dalam membuat laporan polisi model A atau laporan polisi model B. Langkah selanjutnya yang dilakukan oleh polisi berdasarkan Pasal 6 PERKAP Penyidikan Tindak Pidana, beberapa kasus tindak pidana tidak harus sampai proses persidangan, tetapi dapat dilakukan penyelesaian dengan cara restorative justice system atau keadilan restoratif, artinya penyelesaian perkara tindak pidana dengan melibatkan pelaku, korban, keluarga pelaku/korban, dan pihak lain yang terkait untuk bersama-sama mencari penyelesaian yang adil. Penanganan itu menekankan pemulihan kembali pada keadaan semula, dan bukan pembalasan. Hal tersebut yang menjadi salah satu semangat lahirnya PERKAP Penyidikan Tindak Pidana, sehingga penanganan suatu tindak pidana wajib melakukan mediasi antara korban dan pelaku, dan penyelesaian perkara melalui cara keadilan restoratif harus memenuhi ketentuan Pasal 12 PERKAP Penyidikan Tindak Pidana, yakni tidak menimbulkan keresahan atau penolakan masyarakat, dan tidak berdampak konflik sosial, serta adanya pernyataan semua pihak yang terlibat untuk tidak keberatan, sehingga PERKAP Penyidikan Tindak Pidana memaksimalkan penegakan hukum kearah kemanfaatan dari pada kepastian hukum.

\section{B. Penegakan Hukum Terhadap Pelaku} Tindak Pidana Kekerasan Dalam rumah Tangga.

Perlindungan yang dijanjikan oleh UU PKDRT merupakan ide abstrak, dan tidak akan pernah menjadi nyata apabila hukum dibiarkan hanya sebatas tersusun di lembaran naskah atau sekedar diumumkan keberlakuannya kepada masyarakat. Maka, untuk mewujudkan gagasan dan rancangan yang diidealkan menjadi kenyataan diperlukan suatu upaya dan proses penyelarasan. Proses itulah yang disebut penegakan hukum ${ }^{12}$. Dalam penegakan hukum dikenal mekanisme dengan tujuan dan cara yang ingin dicapai adalah kepastian. Pelanggaran terhadap UU PKDRT dalam lingkup rumah tangga sebagaimana dimaksud dalam Pasal 4 dan Pasal 5 huruf a dipidana dengan pidana penjara paling lama 5 tahun atau denda paling banyak Rp15.000.000,-. Hukum dalam praktiknya memiliki logika sendiri, yakni logika sosial yang kompleks yang sangat tergantung konteks dimana masyarakat itu berada. Mewujudkan hukum dalam kenyataan tidak sama dengan menciptakan suatu produk yang sudah didesain dan dibuat cetakannya. Perspektif sosiologis mengandaikan penegakan hukum sebagai proses empiris yang tidak selalu searah dengan prinsip logika matematis yang penuh kepastian sebagaimana hasil penglihatan paradigma normatif positivistik yang telah dikemukakan diatas. Penegakan hukum, karena melibatkan manusia dan masyarakat yang kompleks diyakini juga akan menghasilkan pengalaman dan praktik yang kompleks pula, selalu membuka kemungkinan dan pilihan. Belum tentu satu pasal undang-undang yang sama ketika dilanggar oleh dua orang yang berbeda akan ditegakkan dengan cara yang sama dan oleh karena itu menghasilkan dampak yang sama pula.

Selaras dengan pendapat Satjipto dan Friedman, Surjono Sukanto menyebutkan lima

${ }^{12}$ Munir Fuady, Paradigma Ketidakberdayaan Hukum, Citra Aditya Bakti, Bandung, 2003, hal. 39. 
Media Komunikasi dan Informasi Hukum dan Masyarakat

faktor yang menentukan efektivitas penegakan hukum, yaitu kaidah hukum, fasilitas penegakan hukum, aparat hukum, kesadaran masyarakat dan budaya hukum. Dalam rangka melihat penegakan hukum KDRT di Indonesia, penelitian ini memilih komponen yang ditentukan oleh Soerjono Soekanto sebagai alat analisis, yaitu kaidah hukum, fasilitas penegakan hukum, aparat hukum, kesadaran masyarakat dan budaya hukum ${ }^{13}$.

Upaya kepolisian terhadap penegakan hukum tindak pidana kekerasan dalam rumah tangga yaitu polisi sebagai aparat penegak hukum dalam menangani kasus KDRT melalui pendekatan secara non penal yaitu upaya mediasi, pertimbangannya dengan mengupayakan dan mengutamakan keutuhan rumah tangga korban dan pelaku, terlebih ketika sudah ada anak dari hasil perkawinan para pihak. Namun, jika memang tidak ada titik temu dan kesepakatan dari korban dan pelaku, terlebih lagi ketika korban berkeras untuk proses hukum, maka kita lanjutkan ke penegakan hukum ${ }^{14}$.

Selanjutnya dasar hukum yang digunakan kepolisian dalam penegakan hukum terhadap kasus kekerasan dalam rumah tanggaterdapat pada Pasal 12 PERKAP Tentang Penyidikan Tindak Pidana, yang pada intinya menyebutkan, dalam proses penyidikan dapat dilakukan keadilan restoratif, apabila terpenuhi syarat materiel, dan syarat formil. Syarat materiel meliputi tindak pidana tidak menimbulkan keresahan masyarakat atau tidak ada penolakan masyarakat, tidak berdampak konflik sosial, adanya pernyataan dari semua

${ }^{13}$ Mohammad Hatta, Sistem Peradilan Pidana Terpadu, Galang Presss, Yogyakarta, 2008, hal. 4.

${ }^{14} \mathrm{Hasil}$ Wawancara dengan AKP. Madianta $\mathrm{Br}$. Ginting selaku Kanit PPA Polrestabes Medan, tanggal 22 Juni 2020, pukul $10.00 \mathrm{Wib}$. pihak yang terlibat untuk tidak keberatan, dan melepaskan hak menuntutnya di hadapan hukum, serta prinsip pembatas pada pelaku bahwa tingkat kesalahan pelaku relatif tidak berat, yakni kesalahan dalam bentuk kesengajaan, dan pelaku bukan residivis, selanjutnya pada tindak pidana sebelum SPDP dikirim ke Penuntut Umum. Sedangkan syarat formil meliputi surat permohonan perdamaian kedua belah pihak (pelapor dan terlapor), surat pernyataan perdamaian (akte dading) dan penyelesaian perselisihan para pihak yang berperkara (pelapor, dan/atau keluarga pelapor, terlapor dan/atau keluarga ${ }^{15}$.

Sedangkan penegakan hukum terhadap tindak pidana kekerasan dalam rumah tangga hampir tidak terdapat perbedaan, sebab kejahatan tersebut dibedakan menjadi empat jenis, terutama yang lebih muda untuk dideteksi tindak pidananya adalah kekerasan fisik karena hanya dengan visum et repertum sudah dapat dibuktikan tindak pidana kekerasan fisik tersebut, namun dalam hal penanganan terhadap kekerasan psikis dan penelantaran kita rujuk ke psikiater, dan dilakukan tiga kali pertemuan, sekaligus kalau ada ditemukan oleh dokter ada mengalami tekanan psikis sekaligus untuk pemulihannya, biasanya dengan dokter psikiater yang ada di Rs. Pirngadi atau Rs. Bhayangkara. Sebenarnya pendekatan emosional itu lebih kepada korban kekerasan psikis, kalau seksual jarang, mungkin korban malu melaporkan hal tersebut, selama saya tugas disini belum ada dalam data kami temukan, mungkin korbannya malu dan menganggap sudah kewajibannya untuk melayani suami, meskipun sebenarnyadidalam

${ }^{15}$ Hasil Wawancara dengan AKP. Madianta $\mathrm{Br}$. Ginting selaku Kanit PPA Polrestabes Medan, tanggal 22 Juni 2020, pukul $10.00 \mathrm{Wib}$. 
Media Komunikasi dan Informasi Hukum dan Masyarakat

undang-undang diatur bagi wanita yang sedang haid atau sakit berhak untuk menolak berhubungan suami istri, tapi kemungkinan korban memilih diam karena takut jika hal ini diungkapkan justru menjadi masalah besar dalam rumah tangga, menurut korban ini aib dan menjadi pemicu untuk terjadinya kekerasan fisik dan psikis ${ }^{16}$.

\section{Hambatan dan Upaya Kepolisian Dalam Penegakan Hukum Terhadap Pelaku Tindak Pidana Kekerasan Dalam Rumah Tangga.}

Terkait dengan hambatan yang dihadapi aparat penegak hukum di tingkat kepolisian adalah belum adanya pengaturan dalam UU PKDRT ataupun SOP POLRI yang menyebutkan secara tegas bahwa penelantaran secara ekonomi baru dapat di proses apabila isteri tidak dinafkahi selama tiga bulan secara berturut-turut oleh suami, sehingga dalam prakteknya, penyidik selalu meminta saksi ahli dari departemen agama, karena hal tersebut dalam taklik talak ada diatur, jika tidak dinafkahi selama tiga bulan berturut-turut, hal inilah yang menjadi dasar polisi untuk memproses pengaduan dari pelapor ${ }^{17}$.

Hambatan berikutnya yang dihadapi oleh penegak hukum khususnya polisi adalah ketika pelapor beragama non muslim, sebab taklik talak tersebut hanya dijumpai pengaturannya dalam Kompilasi Hukum Islam yang hanya diberlakukan bagi pemeluk agama islam, namun kenyataannya hal ini dijadikan polisi sebagai rujukan dalam penegakan hukum untuk memproses pelaku tindak pidana

\footnotetext{
${ }^{16}$ Hasil Wawancara dengan AKP. Madianta Br. Ginting selaku Kanit PPA Polrestabes Medan, tanggal 22 Juni 2020, pukul 10.00 Wib.

${ }^{17}$ Hasil Wawancara dengan AKP. Madianta Br. Ginting selaku Kanit PPA Polrestabes Medan, tanggal 22 Juni 2020, pukul 10.00 Wib.
}

kekerasan dalam rumah tangga, sehingga terjadi disintegrasi pengaturan dan penerapan dalam penegakan hukum terfhadap pelaku tindak pidana kekerasan dalam rumah tangga ${ }^{18}$. Selain hal tersebut, hambatan berikutnya adalah suami yang tidak punya pekerjaan, tapi kasus penelantarannya tetap diproses dan diajukan P21, yang jadi pertimbangan APH adalah upaya yang dilakukan dari terlapor apa, ada tidak upayanya untuk mencari pekerjaan, karena kalau dari faktor kemalasan saja dijadikan alasan terlapor tidak bekerja, makanya pada waktu pengambilan keterangan harus benarbenar dipertajam, karena jika hanya kemalasan dari Terlapor dijadikan alasan tidak punya pekerjaan dan tidak dapat menafkahi istrinya, hal ini tidak dapat dijadikan alasan ${ }^{19}$.

Upaya yang dilakukan polisi dalam penegakan hukum terhadap pelaku tindak pidana kekerasan dalam rumah tangga adalah membantu Pelapor dan Terlapor untuk dapat duduk bersama dalam menyelesaikan konflik yang terjadi diantara kedua belah pihak dengan melibatkan tokoh agama, tokoh masyarakat, serta pihak lain yang dianggap berkopeten dalam menyelesaikan konflik kekerasan dalam rumah tangga, sebab tujuannya agar para pihak dapat kembali lagi bersatu menjalani rumah tangga dengan tidak melihat kepada kesalahan masing-masing, namun lebih kepada pemulihan para pihak ke kondisi semula sebelum terjadinya tindak pidana.

Selain hal tersebut, harapannya dipertegas UU PKDRT melalui revisi UU ataupun dibentuk SOP dalam penegakan

${ }^{18}$ Hasil Wawancara dengan AKP. Madianta $\mathrm{Br}$. Ginting selaku Kanit PPA Polrestabes Medan, tanggal 22 Juni 2020, pukul 10.00 Wib.

${ }^{19}$ Hasil Wawancara dengan AKP. Madianta $\mathrm{Br}$. Ginting selaku Kanit PPA Polrestabes Medan, tanggal 22 Juni 2020, pukul 10.00 Wib. 
Media Komunikasi dan Informasi Hukum dan Masyarakat

hukum sebagai payung hukum polisi, agar aparat penegak hukum hanya melaksanakan UU yang dibuat oleh pemerintah, karena menjadi dilema bagi aparat penegak hukum, sebab kurang tajam dan mengambang, tidak jelas pagar-pagarnya (batasannya) ${ }^{20}$.

\section{Penutup}

\section{A. Kesimpulan}

Memperhatikan pengaturan hukum terkait penegakan hukum terhadap pelaku tindak pidana kekerasan dalam rumah tangga terdapat pada KUHAP, UU Kepolisian, dan secara lex spesialis diatur mulai Pasal 4 sampai dengan Pasal 55 UU PKDRT. Penegakan hukum terhadap pelaku tindak pidana pada penjatuhan sanksi pidana semata berupa hukuman badan dijadikan sebagai ultimum remedium, disebabkan pertimbangan sosiologis untuk memperbaiki serta mempertahankan keutuhan rumah tangga, terlebih ketika ada anak dari hasil perkawinan, sehingga meminimalisir pelanggaran-pelanggaran terhadap hak anak. Hambatan yang dihadapi polisi dalam penegakan hukum adalah belum terdapat sinkronisasi dan belum terintegrasinya ketentuan peraturan perundang-undangan terkait penegakan hukum pelaku tindak pidana kekerasan dalam rumah tangga.

\section{B. Saran}

Saran penulis agar pengaturan hukum terkait penegakan hukum terhadap pelaku pidana kekerasan dalam rumah tangga di sinkronisasikan, supaya terciptanya kepastian hukum dalam penegakan hukumnya, sebab banyaknya kasus KDRT mengindikasikan bahwa penangkapan, penahanan dan

\footnotetext{
${ }^{20}$ Hasil Wawancara dengan AKP. Madianta $\mathrm{Br}$. Ginting selaku Kanit PPA Polrestabes Medan, tanggal 22 Juni 2020, pukul 10.00 Wib.
}

penghukuman/ pemenjaraan terhadap pelaku dengan hukum bukan lagi merupakan upaya yang terakhir (ultimum remidium) dalam proses penegakan hukum. Negara harus tetap mengupdate peraturan sesuai dengan kebutuhan hukum masyarakat demi tercipatanya keadilan, kepastian dan kemanfaatan hukum.

\section{DAFTAR PUSTAKA}

\section{A. Buku}

Barda Nawawi Arief, Beberapa Aspek Kebijaksanaan Penegakan dan Pengembangan Hukum Pidana, Citra Aditya Bakti, Bandung, 1998.

Badriyah Khaleed, Penyelesaian Hukum KDRT, Pustaka Yustisia, Jakarta, Cet. I, 2015.

Eddy, O.S Hiariej, Criminal Justice System in Indonesia, Between Theory and Reality, Asia Law Review Vol. 2, No. 2 December 2005, Korean Legislation Research Institute, 2005.

Mardjono Reksodipoetro, Sistem Peradilan Pidana Indonesia (Peran Penegak Hukum Melawan Kejahatan), Pusat Pelayanan Keadilan dan Pengabdian Hukum Universitas Indonesia, 1994.

Michael Cavadino dan James Dignan, The Penal Sistem An Introduction, SAGE Publication Ltd, 1997.

Munir Fuady, Paradigma Ketidakberdayaan Hukum, Citra Aditya Bakti, Bandung, 2003.

M. Taufik Makarao dan Suhasril, Hukum Acara Pidana Dalam Teori Dan Praktek, Ghalia Indonesia, Jakarta, 2004.

Mohammad Hatta, Sistem Peradilan Pidana Terpadu, Galang Presss, Yogyakarta, 2008.

Moerdati Hadiati Soeroso, Kekerasan dalam Rumah Tangga dalam Persfektif Yuridis Viktimologi, Sinar Grafika, Cet II, Jakarta, 2011.

Romli Atmasasmita, Sistem Peradilan pidana (Perspektif Eksistensialisme dan 
Media Komunikasi dan Informasi Hukum dan Masyarakat

Abolisionisme), Mandar Maju, Bandung, 1996.

\section{B. Peraturan Perundang-Undangan}

Undang-Undang Dasar Negara Republik Indonesia Tahun 1945.

Kitab Undang-Undang Hukum Acara Pidana.

Kitab Undang-Undang Hukum Pidana.

Undang-Undang Republik Indonesia Nomor 1 Tahun 1974 tentang Perkawinan.

Undang-Undang Republik Indonesia Nomor 2 Tahun 2002 Tentang Kepolisian Republik Indonesia.

Undang-Undang Republik Indonesia Nomor 23 Tahun 2004 Tentang Penghapusan Kekerasan Dalam Rumah Tangga.

Peraturan Kepala Kepolisian Republik Indonesia Nomor 6 Tahun 2019 Tentang penyidikan Tindak Pidana.

\section{Jurnal}

https://ejurnal.peraturan.go.id/index.php/ili/article /view/299/184, diakses pada tanggal 22 Juni 2020, pukul 22.00 Wib. 